\title{
Changes in Smoking Habits in Pregnant Women During COVID-19 Pandemic. A Comparison of Two Cohorts
}

Javier Llorca ( $\sim$ javier.Ilorca@unican.es )

Universidad de Cantabria

Carolina Lechosa-Muñiz

Universidad de Cantabria

Veronica Vejo-landalia

Hospital Universitario Marqués de Valdecilla

Sonia Vilanova-Fernández

Hospital Universitario Marqués de Valdecilla

Trinidad Dierssen-Sotos

Universidad de Cantabria

Maria Paz-Zulueta

Universidad de Cantabria

Maria J Cabero-Perez

Universidad de Cantabria

\section{Research Article}

Keywords: covid-19, pregnancy, smoking

Posted Date: August 2nd, 2021

DOl: https://doi.org/10.21203/rs.3.rs-736105/v1

License: (9) (i) This work is licensed under a Creative Commons Attribution 4.0 International License.

Read Full License 


\section{Abstract}

Background: Although smoking in pregnancy has well known deleterious effects, about $50 \%$ women who smoked out of the pregnancy continue to smoke while pregnant. The main is to study changes in smoking in pregnancy during covid-19 pandemic.

Methods: We compare two cohorts of pregnant women: one recruited in 2018 (pre-pandemic cohort) and one recruited from March 2020 on (pandemic cohort).

Results: The percentage of women who smoked decreased from $13 \%$ in the pre-pandemic cohort to $8 \%$ in the pandemic cohort $(p<0.001)$. This step-down was similar in all age groups and both employed and unemployed/no active women. Among women in the pandemic cohort, those whose pregnancy began after March-2020 (when the pandemic was declared) reported 1\% smoking prevalence, which is much lower than smoking prevalence in women whose pregnancy began before the pandemic was declared.

Conclusion: Smoking was less frequent in pregnancies during the covid-19 pandemic and even less frequent in women whose pregnancy began after the pandemic was declared. The effect that lockdown, stay-at-home orders or healthier behaviour habits could have had on smoking in pregnancy would require further research.

Trial registration: The study was approved by the Clinical Research Ethics Committee of Cantabria (reference: 2020.174).

\section{Background}

Smoking tobacco in pregnancy is well known as deleterious for both mother and baby health $[1,2]$. Although some studies showed a tendency towards decreasing prevalence [3], more than $50 \%$ women who smoked daily out of the pregnancy continued to smoke while pregnant [4]. The pandemic of covid-19 has led to changes in health-related behaviour, including mask use, stay-at-home orders and others, which have induced some beneficial effects regarding diseases other than covid-19; for instance, the 2021 outbreak of influenza has been much lower than usual or even inexistent $[5,6]$. Although some studies have reported changes in habits during the pandemic [6], only a few small qualitative studies have analysed behavioural changes in pregnant women during the pandemic [7-9]. Therefore, little is known about whether pregnant women have increased, decreased or maintained their habits in this period.

In this article, we study changes in smoking habit during pregnancy comparing two cohorts: one recruited in 2018 -before the pandemic began- and another recruited from March 2021 -when the pandemic was ongoing- in a single hospital located in Northern Spain.

\section{Methods}

\section{Setting and patients}


This is a joint analysis of two cohorts recruited at the University Hospital Marques de Valdecilla (HUMV), Cantabria, Spain. Pre-pandemic cohort was recruited in 2018 and included 948 pregnant women and their children. Their main characteristics have been described elsewhere $[10,11]$. In brief, women were consecutively recruited between 1st January and 31st August 2018. In order to participate in the cohort, they should have been admitted for delivery in the HUMV and reside in the region were the HUMV is (Cantabria, Northern Spain).

The pandemic cohort was recruited in 2020. Its profile has been already reported [12]. Recruitment began on 26th May and finished on 22nd October. This cohort was composed by three sub-cohorts. Sub-cohort 1 was retrospectively recruited and includes women delivering at HUMV between 23rd March (the first date the hospital introduced routinely SARS-CoV-2 infection test via PCR for all women admitted for delivery) and 25th May, 2020. Sub-cohort 2 was prospectively recruited and includes women delivering at HUMV from 26th May on. Sub-cohort 3 was prospectively recruited and includes women attended at HUMV for their routine 12-week of pregnancy consultation; many of their pregnancies are still ongoing when carrying on this analysis. The rationale for these three sub-cohorts is to differentiate the pandemic consequences in pregnancy according to the period of risk for each woman, which was as follows: women in the first sub-cohort were neither exposed to nor aware of SARS-CoV-2 for most of their pregnancy, and their exposition was limited to the last trimester of pregnancy, which mostly coincided with the first pandemic wave. Women in the second sub-cohort could have been both exposed to and aware of the pandemic from their second trimester of pregnancy, which coincided with the first pandemic wave, while their third trimester was concurrent with the lower levels of covid-19 incidence between the first and the second waves. Finally, women in the third sub-cohort were aware of the pandemic all throughout their pregnancy and their exposition was higher in the second and posterior waves.

\section{Gathered information}

Information on maternal educational level (classified as primary school, secondary school, vocational training and university), occupational situation (classified as employed, unemployed or inactive, student) was self-reported. Age, number of previous children, length of pregnancy (later classified as less than 34 weeks, 34-36 weeks +6 days, 37 weeds or more), type of delivery (eutocic, instrumental or Caesarean section), weight at birth (later classified as less than 2500 grams, 2500-4000 grams and more than 4000 grams) and type of feeding at hospital discharge (exclusive breastfeeding, mixed -breastfeeding and artificial formula-, and formula) were obtained from medical records. Smoking habit in pregnancy and averaged daily number of cigarettes in pregnancy were obtained as reported by the pregnant women.

\section{Statistical analysis}

In this article, we compare the pre-pandemic and the pandemic cohorts with each other, regarding the smoking habit in pregnancy and its association with pregnancy, delivery and neonate characteristics. We also carry on the same comparison between all three sub-cohorts in the pandemic cohort.

Association between smoking and cohort according to woman, pregnancy or child characteristics was tested using Chi-square test and association between the average daily number of cigarettes and cohort 
according to the same characteristics was tested using the Student's t test. Results are provided as number with percentage or mean with standard deviation. Odds ratios and their $95 \%$ confidence intervals were obtained to compare smoking in pregnancy in the pandemic and the pre-pandemic cohorts, using the later as reference. Therefore, odds ratios lower than 1 indicate that smoking was less frequent in the pandemic cohort, while odds ratios over 1 indicate that smoking was more frequent in the pandemic cohort. All p values are two-tailed.

\section{Results}

In this study, 2116 pregnant women were included; 948 belonging to the pre-pandemic cohort and 1168 to the pandemic one. Among the pandemic cohort, 270 women were retrospectively recruited and had delivered a bay before 26th May, 2020 (sub-cohort 1); 350 were prospectively recruited at delivery from 26th May, 2020 on (sub-cohort 2), and 548 were prospectively recruited at week 12 of pregnancy (subcohort 3). Only 53 women in sub-cohort 3 had already delivered a baby by the time of this analysis, so this sub-cohort was excluded regarding variables related to delivery. Supplementary Table 1 provides the description of the participants. Smoking in pregnancy was less frequent in the pandemic cohort $(8 \%)$ than in the pre-pandemic one $(13 \%)(p<0.001)$. Both cohorts also differed in educational attainment, occupational situation, type of delivery, length of pregnancy and weight at birth.

The association between smoking in pregnancy and cohort, according to maternal characteristics is depicted in Table 1. In the pandemic cohort, the percentage of pregnant women smoking was smaller than in the pre-pandemic cohort in all maternal ages, although a statistically significant result was only reached in the $28-34$ years group (odds ratio $[\mathrm{OR}]=0.60,95 \%$ confidence interval $[\mathrm{Cl}]=0.39-0.92, p=$ $0.02)$. Decreases in smoking in the pandemic cohort were also observed in employed $(\mathrm{OR}=0.67,95 \% \mathrm{Cl}$ : $0.46-0.97, p=0.02)$ and unemployed/no active ( $\mathrm{OR}=0.50,95 \% \mathrm{Cl}: 0.29-0.85, \mathrm{p}=0.007)$. The relationships between number of cigarettes a day and cohort according to maternal characteristics appears in Supplementary Table 2. 
Table 1

Association between smoking in pregnancy and maternal characteristics

\begin{tabular}{|c|c|c|c|c|}
\hline Variable & $\begin{array}{l}\text { Pre-pandemic } \\
\text { cohort (2018) } \\
\text { n smoking / n } \\
\text { total (\%) }\end{array}$ & $\begin{array}{l}\text { Pandemic } \\
\text { cohort } \\
(2020) \\
\text { n smoking } \\
\text { / n total (\%) }\end{array}$ & $\begin{array}{l}\text { Odds ratio and } 95 \% \mathrm{Cl} \text { (pre- } \\
\text { pandemic cohort is the } \\
\text { reference) }\end{array}$ & $\begin{array}{l}\text { p value } \\
\text { comparing both } \\
\text { cohorts }\end{array}$ \\
\hline \multicolumn{5}{|l|}{ Maternal age } \\
\hline$<24$ years & 12/36 (33) & $9 / 38(24)$ & $0.62(0.20-1.93)$ & 0.36 \\
\hline $24-27$ years & $10 / 85(12)$ & $\begin{array}{l}12 / 117 \\
(10)\end{array}$ & $0.86(0.32-2.34)$ & 0.73 \\
\hline $28-34$ years & $60 / 411(15)$ & 45/487 (9) & $0.60(0.39-0.92)$ & 0.02 \\
\hline $35-40$ years & $33 / 363(9)$ & 28/477 (6) & $0.62(0.36-1.09)$ & 0.08 \\
\hline$>40$ years & 7/74 (9) & 2/72 (3) & $0.27(0.03-1.52)$ & 0.09 \\
\hline \multicolumn{5}{|l|}{$\begin{array}{l}\text { Order of } \\
\text { birth* }\end{array}$} \\
\hline First & 73/507 (14) & $\begin{array}{l}53 / 377 \\
(14)\end{array}$ & $0.97(0.65-1.45)$ & 0.89 \\
\hline Other & 49/413 (11) & $\begin{array}{l}43 / 313 \\
(14)\end{array}$ & $0.86(0.55-1.36)$ & 0.45 \\
\hline \multicolumn{5}{|l|}{$\begin{array}{l}\text { Educational } \\
\text { level }\end{array}$} \\
\hline $\begin{array}{l}\text { Primary } \\
\text { school }\end{array}$ & $41 / 215(19)$ & $\begin{array}{l}31 / 178 \\
(17)\end{array}$ & $0.89(0.52-1.55)$ & 0.67 \\
\hline $\begin{array}{l}\text { Secondary } \\
\text { school }\end{array}$ & $22 / 114(19)$ & 8/77 (10) & $0.48(0.18-1.22)$ & 0.10 \\
\hline $\begin{array}{l}\text { Vocational } \\
\text { training }\end{array}$ & $41 / 281(15)$ & $\begin{array}{l}42 / 379 \\
(11)\end{array}$ & $0.73(0.45-1.19)$ & 0.18 \\
\hline University & 18/341 (5) & 15/553 (3) & $0.50(0.23-1.07)$ & 0.05 \\
\hline \multicolumn{5}{|l|}{$\begin{array}{l}\text { Occupational } \\
\text { situation }\end{array}$} \\
\hline Employed & $72 / 673(11)$ & $66 / 890(7)$ & $0.67(0.46-0.97)$ & 0.02 \\
\hline $\begin{array}{l}\text { Unemployed } \\
\text { / no active }\end{array}$ & $50 / 286(18)$ & $\begin{array}{l}27 / 280 \\
(10)\end{array}$ & $0.50(0.29-0.85)$ & 0.007 \\
\hline Student & $0 / 10(0)$ & $3 / 18(17)$ & - & 0.17 \\
\hline
\end{tabular}


Table 2 reported the association between smoking in pregnancy and cohort, according to delivery type and neonate characteristics. Of note, this analysis does not include pregnancies from the sub-cohort 3 of the pandemic cohort. Smoking was more frequent in the pandemic cohort if delivery took place at term $(\mathrm{OR}=1.38,95 \% \mathrm{Cl}: 1.01-1.88, \mathrm{p}=0.04)$. In the remaining characteristics, smoking was similar between both cohorts. The association between number of cigarettes a day and cohort according to delivery/neonate characteristics is displayed in Supplementary Table 3. 
Table 2

Association between smoking and delivery / neonate characteristics. In the pandemic cohort, only pregnancies in sub-cohorts 1 and 2 are included

\begin{tabular}{|c|c|c|c|c|}
\hline Variable & $\begin{array}{l}\text { n smoking / } \\
\text { n total (\%) }\end{array}$ & $\begin{array}{l}\text { Pandemic } \\
\text { cohort } \\
\text { (2020) } \\
\text { n smoking } \\
\text { / n total (\%) }\end{array}$ & $\begin{array}{l}\text { Odds ratio and } 95 \% \mathrm{Cl} \text { (pre- } \\
\text { pandemic cohort is the } \\
\text { reference) }\end{array}$ & $\begin{array}{l}\text { p value } \\
\text { comparing both } \\
\text { cohorts }\end{array}$ \\
\hline \multicolumn{5}{|l|}{$\begin{array}{l}\text { Type of } \\
\text { delivery }\end{array}$} \\
\hline Eutocic & 76/653 (12) & $\begin{array}{l}72 / 510 \\
(14)\end{array}$ & $1.25(0.87-1.79)$ & 0.21 \\
\hline Instrumental & $14 / 80(18)$ & $8 / 47(17)$ & $0.97(0.32-2.74)$ & 0.95 \\
\hline $\begin{array}{l}\text { Caesarean } \\
\text { section }\end{array}$ & $32 / 236(14)$ & $\begin{array}{l}15 / 125 \\
(12)\end{array}$ & $0.87(0.42-1.74)$ & 0.68 \\
\hline \multicolumn{5}{|l|}{$\begin{array}{l}\text { Length of } \\
\text { pregnancy }\end{array}$} \\
\hline$<34$ weeks & $2 / 20(10)$ & $0 / 3(0)$ & $0(0-15.8)$ & 0.57 \\
\hline $34-36^{6}$ weeks & $9 / 39(23)$ & $5 / 33(15)$ & $0.60(0.14-2.28)$ & 0.40 \\
\hline$\geq 37$ weeks & $111 / 910(12)$ & $\begin{array}{l}90 / 561 \\
(14)\end{array}$ & $1.38(1.01-1.88)$ & 0.04 \\
\hline \multicolumn{5}{|l|}{ Weight at birth } \\
\hline$<2500 \mathrm{~g}$ & 19/83 (23) & $11 / 40(28)$ & $1.28(0.48-3.26)$ & 0.58 \\
\hline $2500-4000 \mathrm{~g}$ & 95/808 (12) & $\begin{array}{l}81 / 625 \\
(13)\end{array}$ & $1.12(0.80-1.55)$ & 0.49 \\
\hline$>4000 \mathrm{~g}$ & $8 / 78(10)$ & $3 / 32(9)$ & $0.91(0.14-4.13)$ & 0.89 \\
\hline \multicolumn{5}{|l|}{$\begin{array}{l}\text { Feeding at } \\
\text { hospital } \\
\text { discharge }\end{array}$} \\
\hline $\begin{array}{l}\text { Exclusive } \\
\text { breastfeeding }\end{array}$ & $51 / 521(10)$ & $\begin{array}{l}41 / 410 \\
(10)\end{array}$ & $1.02(0.65-1.61)$ & 0.92 \\
\hline Mixed & $33 / 280(12)$ & $\begin{array}{l}17 / 144 \\
(12)\end{array}$ & $1.01(0.50-1.94)$ & 1.00 \\
\hline Formula & $38 / 168(23)$ & $\begin{array}{l}37 / 126 \\
(29)\end{array}$ & $1.42(0.81-2.49)$ & 0.19 \\
\hline
\end{tabular}

To further analyse changes in smoking during the pandemic, Table 3 displays the relationship between smoking in pregnancy and sub-cohort, according to maternal characteristics. Smoking was less frequent in pregnant women belonging to the sub-cohort $3(1 \%)$ than in sub-cohorts $1(12 \%)$ and $2(15 \%)$, 
irrespective of their age, educational level or occupation situation. Women in sub-cohort 1 and sub-cohort 2 declared similar rates of smoking.

Table 3

Association between smoking in pregnancy and maternal characteristics in pandemic sub-cohorts

\begin{tabular}{|c|c|c|c|c|}
\hline Variable & $\begin{array}{l}\text { Sub-cohort } 1 \\
\text { (delivery before } \\
\text { 26th May, 2020) } \\
\text { n smoking / no } \\
\text { total (\%) }\end{array}$ & $\begin{array}{l}\text { Sub-cohort } 2 \\
\text { (delivery after } \\
\text { 26th May, } \\
\text { 2020) } \\
\text { n smoking / no } \\
\text { total (\%) }\end{array}$ & $\begin{array}{l}\text { Sub-cohort } 3 \text { (recruited in } \\
\text { 12th week of pregnancy } \\
\text { after 26th May, 2020) } \\
\text { n smoking / no total (\%) }\end{array}$ & $\begin{array}{l}\text { p value } \\
\text { comparing all } \\
\text { three sub- } \\
\text { cohorts }\end{array}$ \\
\hline Total & $31 / 266(12)$ & $54 / 350(15)$ & $6 / 541(1)$ & $<0.001$ \\
\hline \multicolumn{5}{|l|}{ Maternal age } \\
\hline$<24$ years & $2 / 7(29)$ & 6/17 (33) & 1/13 (8) & 0.24 \\
\hline $24-27$ years & $3 / 26(12)$ & $8 / 34(24)$ & $0 / 53(0)$ & 0.001 \\
\hline $28-34$ years & 15/102 (15) & $25 / 145$ (17) & $3 / 226(1)$ & $<0.001$ \\
\hline $35-40$ years & 10/115 (9) & $14 / 130(11)$ & $2 / 223(1)$ & $<0.001$ \\
\hline$>40$ years & $1 / 16(6)$ & $1 / 23(4)$ & $0 / 32(0)$ & 0.40 \\
\hline \multicolumn{5}{|l|}{ Order of birth } \\
\hline First & $17 / 132(13)$ & $31 / 203(15)$ & & 0.54 \\
\hline Other & $14 / 134(10)$ & 23/147 (16) & & 0.20 \\
\hline \multicolumn{5}{|l|}{$\begin{array}{l}\text { Educational } \\
\text { level }\end{array}$} \\
\hline $\begin{array}{l}\text { Primary } \\
\text { school }\end{array}$ & $9 / 33(27)$ & $17 / 50(34)$ & $3 / 92$ (3) & $<0.001$ \\
\hline $\begin{array}{l}\text { Secondary } \\
\text { school }\end{array}$ & $2 / 18(11)$ & 4/34 (12) & $1 / 21(5)$ & 0.67 \\
\hline $\begin{array}{l}\text { Vocational } \\
\text { training }\end{array}$ & 17/99 (17) & $21 / 98(21)$ & $2 / 172(1)$ & $<0.001$ \\
\hline University & $3 / 116(3)$ & $12 / 166(7)$ & $0 / 262(0)$ & $<0.001$ \\
\hline \multicolumn{5}{|l|}{$\begin{array}{l}\text { Occupational } \\
\text { situation }\end{array}$} \\
\hline Employed & $20 / 205(10)$ & $38 / 256(15)$ & $4 / 404(1)$ & $<0.001$ \\
\hline $\begin{array}{l}\text { Unemployed } \\
\text { / no active }\end{array}$ & $9 / 56(16)$ & $15 / 89(17)$ & $2 / 132(2)$ & $<0.001$ \\
\hline Student & $2 / 3(67)$ & $1 / 4(25)$ & 0/11(0) & 0.02 \\
\hline
\end{tabular}


In Table 4, smoking in sub-cohorts 1 and 2 in the pandemic is compared according to type of delivery and neo-born characteristics. Smoking was more frequent in sub-cohort 2 if delivery was eutocic ( $17 \%$ vs. $10 \%, p=0.05)$. No other differences were found between both sub-cohorts.

\section{Table 4}

Association between smoking and delivery / neonate characteristics in pandemic sub-cohorts. Only subcohorts 1 and 2 are included as most women in sub-cohort 3 have not delivered yet.

\begin{tabular}{|c|c|c|c|}
\hline Variable & $\begin{array}{l}\text { Sub-cohort } 1 \text { (delivery } \\
\text { before 26th May, 2020) } \\
\text { n smoking / no total (\%) }\end{array}$ & $\begin{array}{l}\text { Sub-cohort } 2 \text { (delivery } \\
\text { after 26th May, 2020) } \\
\text { n smoking / no total (\%) }\end{array}$ & $\begin{array}{l}\text { p value comparing } \\
\text { both cohorts }\end{array}$ \\
\hline \multicolumn{4}{|l|}{ Type of delivery } \\
\hline Eutocic & 20/195 (10) & $44 / 261(17)$ & 0.05 \\
\hline Instrumental & $4 / 19(21)$ & $3 / 21(14)$ & 0.57 \\
\hline $\begin{array}{l}\text { Caesarean } \\
\text { section }\end{array}$ & $7 / 50$ (14) & $6 / 62(10)$ & 0.48 \\
\hline \multicolumn{4}{|l|}{$\begin{array}{l}\text { Length of } \\
\text { pregnancy }\end{array}$} \\
\hline$<34$ weeks & $0 / 2(0)$ & $0 / 1(0)$ & - \\
\hline $34-36^{6}$ weeks & 0/11 (0) & $3 / 10(23)$ & 0.09 \\
\hline$\geq 37$ weeks & $31 / 247$ (13) & $50 / 329(15)$ & 0.37 \\
\hline \multicolumn{4}{|l|}{ Weight at birth } \\
\hline$<2500 \mathrm{~g}$ & 4/17 (24) & $5 / 18(28)$ & 0.77 \\
\hline $2500-4000 \mathrm{~g}$ & 27/236 (11) & $46 / 316(15)$ & 0.29 \\
\hline$>4000 \mathrm{~g}$ & 0/13 (0) & 2/11 (15) & 0.14 \\
\hline \multicolumn{4}{|l|}{$\begin{array}{l}\text { Feeding at } \\
\text { hospital } \\
\text { discharge }\end{array}$} \\
\hline $\begin{array}{l}\text { Exclusive } \\
\text { breastfeeding }\end{array}$ & 12/156 (8) & 27/204 (13) & 0.09 \\
\hline Mixed & $7 / 54(13)$ & $5 / 76(7)$ & 0.22 \\
\hline Formula & $12 / 51(24)$ & 21/57 (37) & 0.13 \\
\hline
\end{tabular}

\section{Discussion}

According to our results, smoking was less frequent in pregnant women during the covid-19 pandemic than in pregnant women in 2018, before the pandemic began. However, this reduction mainly occurred in 
the sub-cohort 3, which is formed by women who became pregnant when the pandemic had already started, rather than in sub-cohorts 1 and 2 whose pregnancies commenced several months before being aware of the pandemic. The cutdown in smoking during sub-cohort 3 seems to be independent of maternal age, educational level and occupational situation.

In the only study we found comparing pandemic and pre-pandemic cohorts, Overbeck et al (2021) [13] reported smoking prevalence in Danish pregnant women cutdown from $6.8 \%$ in $2015 / 16$ to $4.0 \%$ in 2020 during the lockdown. Ceulemans et al (2021) [14], in an international study carried out in Ireland, Norway, Switzerland, The Netherlands and United Kingdom, informed of a smoking prevalence in pregnant women as low as $2.6 \%$ during the pandemic, although they did not inform on a pre-pandemic comparison group. A Spanish cohort reported that prevalence of smoking was $12.8 \%$ in non-SARS-CoV- 2 infected women and $10.2 \%$ in infected women, although these figures include both smokers in pregnancy and former smokers [15].

Other changes in reproductive health behaviour have been described. For instance, Stout et al [16] have informed of a $14 \%$ reduction in pregnancy initiation after the beginning of the pandemic, contrasting with a trend to increase in the same areas throughout the three preceding years. A survey conducted by the Guttmacher Institute reported a trend to delay pregnancy, cancellations of contraceptive or other sexual and reproductive health care [17]. Our group have depicted that maternal leaving of work has been earlier in pregnancies initiated during the pandemic [18]. These changes, together with the decrease in smoking in pregnancy we are reporting, delineate a tendency to self-protective behaviour in pregnant women and women in reproductive age during the pandemic.

The mechanisms for these changes could be multiple. Firstly, the women themselves could have adopted healthier behaviours, which would have been induced by the sense of individual risk as transmitted in media or by governmental spokespersons. Secondly, societal shutdowns and stay-at-home order could have induced those changes, voluntarily or not; by-the-way, early new reported higher risk of covid-19 infection in smokers, which led to restriction or prohibition of smoking in public places (e.g., in terrace bars). Thirdly, health care services have modified their functioning, including -among others- delays of appointments, increase in telemedicine. We have no information to estimate the relative importance of these three factors on changes in reproductive behaviour.

This study has some limitations. Firstly, data on smoking were self-reported, which makes some room to misclassification if some women -being aware of the social rejection on tobacco, especially in pregnancyhave hidden their use. However, we think that this misclassification -if exists- would have been nondifferential between the cohorts we are comparing; so that the decreasing trend would still hold. Secondly, our study has been carried out in a single centre; therefore, further studies are required in other locations to test its generalizability. Among the strengths of this study, we would remark the prospective recruitment of most women and the homogeneous way of recording information.

\section{Conclusions}


In conclusion, we are reporting that smoking prevalence in pregnancy has decreased during the COVID-19 pandemic. This reduction coincides with other changes in reproductive behaviour. Further research is needed to acknowledge whether this cutdown would remain after the pandemic be controlled.

\section{Abbreviations}

University Hospital Marqués de Valdecilla (HUMV)

Odd Ratio (OR)

\section{Declarations}

ACKNOWLEDGEMENTS

Members of the MOACC-19 group:

Jéssica Alonso-Molero, Bárbara Arozamena, Laura Conde-Gil, Rocío Cuesta-González, María FernándezOrtiz, Pelayo Frank de Zulueta, Inés Gómez-Acebo, Pilar Gortázar, Yolanda Jubete, Coral Llano-Ruiz, Lorena Lasarte-Oria, Sonia López-Gómez, Virginia Orallo, Rosa Pardo, Daniel Pérez-González, María Sáez de Adana Herrero.

FUNDING

This research waspartially funded by the Instituto de Salud Carlos III (ISCIII), grant number COV20/00923. AUTHOR'S CONTRIBUTIONS

Conceptualization, J.L. and MJ.CP.; Methodology, C.LM. and V.VI.; Validation, S.VF. and T.DS.; Formal Analysis, J.L.; Investigation, M.PZ.; Data Curation,V.VI. and S.VF.; Writing - Original Draft Preparation, J.L. and C.LM.; Writing - Review \& Editing, T.DS. and MJ.CP;; Visualization, M.PZ.; Supervision, MJ.CP.; Project Administration, MOACC-19 group.; Funding Acquisition, MOACC-19 group.

\section{ETHICS APPROVAL AND CONSENT TO PARTICIPATE}

The study was approved by the Clinical Research Ethics Committee of Cantabria (reference: 2020.174).The study is conducted according to the Declaration of Helsinki (last update of Fortaleza) and the European Union regulation 2016/679 on the protection of natural persons with regard to the processing of personal data.

Informed consent was obtained from all subjects involved in the study.

CONSENT FOR PUBLICATION

Not applicable 
The datasets used and/or analysed during the current study are available from the corresponding author on reasonable request.

\section{COMPETING INTERESTS}

The authors declare that they have no competing interests.

\section{References}

1. Andres RL, Day M-C. Perinatal complications associated with maternal tobacco use. Semin Neonatol. 2000;5:231-41. doi:10.1053/siny.2000.0025.

2. U.S. Department of Health and Human Services. The Health Consequences of Smoking: 50 Years of Progress. A Report of the Surgeon General. Atlanta, GA: U.S. Department of Health and Human Services, Centers for Disease Control and Prevention, National Center for Chronic Disease Prevention and Health Promotion, Office on Smoking and Health. 2014.

3. AlHW. Austria's mothers and babies 2017 - In brief. Canberra, Australia: Australia Institute of Health and Welfare. 2019. www.aihw.gov.au/.

4. Lange S, Probst C, Rehm J, Popova S. National, regional, and global prevalence of smoking during pregnancy in the general population: a systematic review and meta-analysis. Lancet Glob Heal. 2018;6:e769-76. doi:10.1016/S2214-109X(18)30223-7.

5. Olsen SJ, Azziz-Baumgartner E, Budd AP, Brammer L, Sullivan S, Pineda RF, et al. Decreased Influenza Activity During the COVID-19 Pandemic - United States, Australia, Chile, and South Africa, 2020. MMWR Morb Mortal Wkly Rep. 2020;69:1305-9. doi:10.15585/mmwr.mm6937a6.

6. Zipfel CM, Colizza V, Bansal S. The missing season: The impacts of the COVID-19 pandemic on influenza. Vaccine. 2021;39:3645-8. doi:10.1016/j.vaccine.2021.05.049.

7. Kumari A, Ranjan P, Sharma KA, Sahu A, Bharti J, Zangmo R, et al. Impact of COVID-19 on psychosocial functioning of peripartum women: A qualitative study comprising focus group discussions and in-depth interviews. Int J Gynecol Obstet. 2021;152:321-7. doi:10.1002/ijgo.13524.

8. Rice K, Williams S. Women's postpartum experiences in Canada during the COVID-19 pandemic: a qualitative study. C Open. 2021;9:E556-62. doi:10.9778/cmajo.20210008.

9. Mizrak Sahin B, Kabakci EN. The experiences of pregnant women during the COVID-19 pandemic in Turkey: A qualitative study. Women and Birth. 2021;34:162-9. doi:10.1016/j.wombi.2020.09.022.

10. Lechosa Muñiz C, Paz-Zulueta M, Cornejo del Río E, Mateo Sota S, Sáez de Adana M, Madrazo Pérez $M$, et al. Impact of Maternal Smoking on the Onset of Breastfeeding versus Formula Feeding: A Cross-Sectional Study. Int J Environ Res Public Health. 2019;16:4888. doi:10.3390/ijerph16244888.

11. Lechosa-Muñiz C, Paz-Zulueta M, Sota SM, de Adana Herrero MS, del Rio EC, Llorca J, et al. Factors associated with duration of breastfeeding in Spain: a cohort study. Int Breastfeed J. 2020;15:79. 
doi:10.1186/s13006-020-00324-6.

12. Llorca J, Lechosa-Muñiz C, Gortazar P, Fernández-Ortiz M, Jubete Y, Cabero MJ. COVID-19 in a cohort of pregnant women and their descendants, the MOACC-19 study. BMJ Open. 2021;11:e044224. doi:10.1136/bmjopen-2020-044224.

13. Overbeck G, Rasmussen IS, Siersma V, Andersen JH, Kragstrup J, Wilson P, et al. Depression and anxiety symptoms in pregnant women in Denmark during COVID-19. Scand J Public Health. 2021;: (Online ahead of print). doi:10.1177/14034948211013271.

14. Ceulemans M, Foulon V, Ngo E, Panchaud A, Winterfeld U, Pomar L, et al. Mental health status of pregnant and breastfeeding women during the COVID-19 pandemic-A multinational cross-sectional study. Acta Obstet Gynecol Scand. 2021;:(Online ahead of print). doi:10.1111/aogs.14092.

15. Cruz Melguizo S, de la Cruz Conty M, Carmona Payán P, Abascal-Saiz A, Pintando Recarte P, González Rodríguez L, et al. Pregnancy Outcomes and SARS-CoV-2 Infection: The Spanish Obstetric Emergency Group Study. Viruses. 2021;13:853. doi:10.3390/v13050853.

16. Stout MJ, Van De Ven CJM, Parekh VI, Pardo JL, Garifullin M, Xu M, et al. Use of Electronic Medical Records to Estimate Changes in Pregnancy and Birth Rates During the COVID-19 Pandemic. JAMA Netw Open. 2021;4:e2111621. doi:10.1001/jamanetworkopen.2021.11621.

17. Lindberg L, Van de Vusse A, Mueller J, Kirstein M. Early impacts of the COVID-19 pandemic: findings from the 2020 Guttmacher Survey of Reproductive Health Experiences. New York: Guttmacher Institute. 2020. https://www.guttmacher.org/sites/default/files/report_pdf/early-impacts-covid-19pandemic-findings-2020-guttmacher-survey-reproductive-health.pdf. Accessed 5 Jun 2021.

18. Llorca J, Lechosa-Muñiz C, Frank de Zulueta P, Lopez-Gomez S, Orallo V, Alonso-Molero J, et al. Results of Pregnancy Control before and during the Covid-19 Pandemic: A Comparison of Two Cohorts. Preprints. 2021;2021060538.

\section{Supplementary Tables}

Supplementary Tables are not available with this version 